\title{
Technological Innovations - A linking Instrument towards Sustainable Development
}

\author{
Dr. Ajaz Akbar Mir \\ Assistant Professor, The Business School, University of Kashmir \\ Sher Jahan Khan \\ Research Scholar, The Business School, University of Kashmir
}

\begin{abstract}
Over the past few decades, countries around the globe have witnessed huge economic growth as their main focus was on maximising material gains without any concern for the future generations. Due to the continuous exploitation of natural resources and heavy concentration of greenhouse gases into the environment, our future generations are facing a threat, as we may lose our natural resource base forever due to climate change. It is predicted that climate change can alter the years of development if necessary action is not taken. As technology is playing a crucial role in every field these days, researchers are coming up with innovative ideas that are contributing towards a sustainable world. The present study aims at highlighting the various technological advances in India and around the globe that are contributing towards the sustainable development of global economies.
\end{abstract}

Key Words: Sustainable Development, Technological Advances, Innovation, Efficiency.

I. INTRODUCTION

In the last few decades the world has witnessed massive economic growth rates, pulling out millions of people out of poverty. However, due to continuous extraction of fossil fuels, deforestation, wastage of water resources, increasing pollution levels and rise in Greenhouse gases in the environment, earth's climate has changed. It is estimated that oceans hold $97 \%$ of the world's water resources, $2 \%$ comprises of glaciers and the remaining $1 \%$ is in our lakes and rivers [1]. With rising temperature levels due to global warming, our future generations are facing a water crisis as we may lose glaciers forever. Furthermore it can cause ocean temperature to rise resulting in frequent storms and heavy rainfall and floods.Climate change is also damaging the natural habitat as rising temperatures are increasing the incidences of wildfires. Since the main cause of climate change is the increasing amount of greenhouse gases released into the atmosphere by burning of fossil fuels, mainly oil and coal, the world is moving towards renewable energy resources like solar, wind, thermal, tidal energy etc., which are not only clean energy sources but are important for the sustainable development of the world. If the amount of greenhouse gases released into the environment is not decreased, it can have serious implications on our future generations. Rising levels of greenhouse gases can affect our health, food supply and water resources. However, new technological innovations are playing a great role in reducing the greenhouse gas emissions while providing the world with clean energy. An attempt has been made to cover the many areas in which technology is playing a crucial role to tackle the problems faced by the world today.

\section{ROLE OF TECHNOLOGY IN AGRICULTURE}

It is estimated that by 2050 the population of the world will reach 9.6 billion [2] from the current 7.3 billion. 1 in eight people goes to bed hungry each night. Of the 842 million malnourished people in the world, 300 million are children; 553 million are from Asia Pacific Countries, while 227 million are from sub-Saharan Africa [3]. It is quite disturbing given the fact that Asia and Africa account for 95\% of global agricultural population [4]. Given these figures it is very much important not only to increase the food production, so that the future generations can be fed, but also to look for ways to reduce inefficiencies. This is made possible by the advances in technology. Crops are genetically modified to make them resistant to weeds, insects and diseases which in turn increase crop productivity. Although the Government has only allowed Bt cotton cultivation in the country, nonetheless Indiais the 4th largest in terms of Genetically Modified crop acreage [5] and the Government is likely to allow GM crops in order to achieve the second green revolution target. But only modifying the crops won't solve the food shortages around the globe. It is estimated that globally one third of the food produced gets wasted due to inappropriate storage and transport facilities. India alone loses fruits and vegetables worth Rs. 13300 crore every year [6]. Though there are around 6300 cold storage facilities in the country, but that is roughly half of what India needs. To tackle the high cost of setup and maintenance of cold storagefacilities, 
engineers at the IIT Kharagpur have come up with an affordable solution by developing a solar powered cold storage system which doesn't require batteries to store energy but a thermal storage unit which can store power for more than 36 hours [7]. Information and communication facilities have also contributed a lot in increasing the productivity of our farmlands while cutting down on costs. India has opened a Kisan call centre which answers the queries of farmers. Also text messages are sent to the farmers to inform them about the weather forecastsand the amount of water and fertilisers to be put into the fields.

\section{ROLE OF TECHNOLOGY IN HEALTHCARE}

Biomedical waste generated by hospitals has become a cause of concern for the environmental degradation that it causes. Every year tonnes of waste are generated by hospitals globally and as per estimates $85 \%$ of this waste is non-hazardous [8]. Earlier this waste was incinerated but that produced a lot of toxins. There are however many non-incineration technologies available to treat the waste. Autoclaving is one such technique used most often for treating biomedical waste. This process uses high pressure steam to disinfect the waste before it is disposed or sent for recycling. Likewise, many other technologies are used to reduce the amount of energy required to run the hospital equipment. Millions of people, particularly in Asia and Africa lack access to hospitals or other clinical laboratories. As per estimates, for every thousand Indians, there are only 0.7 [9], making it difficult for poor people to access basic healthcare facilities. However, as technology is progressing, new innovative devices are created to tackle these problems. One such innovative device has been invented by an Indian researcher which can measure body temperature, ECG, blood type and also other diagnostic tests like malaria, dengue, typhoid, hepatitis B and a variety of other tests. The device is estimated to be $95 \%$ accurate while being affordable. Further the device can be used by midwives or other community health workers to administer basic treatment [10]. This technology transmits the data to central database which, apart from the doctors, can be used by the government officials to formulate better healthcare policies. In Africa thousands of people are dying each year due to HIV and other deadly diseases, as they do not afford the costs associated with diagnostic tests. Taking a cue from this, researchers from US and Rwanda have developed a device that can detect Syphilis and HIV in less than 15 minutes from a drop of blood. The dongle which costs only \$34, as against the $\$ 18000$ ELISSA assay system currently in practise, can reduce the deaths by 10 -folds [11].

\section{ROLE OF TECHNOLOGY IN SUPPLYING CLEAN WATER}

Due to ever increasing population the demand for clean water for drinking and sanitation is growing. As per a report by UN Water, $85 \%$ of the world's population lives in the driest half of the planet, 783 million lack access to clean water [12].To tackle this problem; Governments are using technology to supply pure drinking water to the population. One of the world's largest sea water desalination plant is in Israel and it supplies around $20 \%$ of the country's households [13]. In this process sea water is pumped into a pre-treatment facility where sediments, viruses and other bacteria are filtered before the water is pushed into a filtration chamber for desalination. The desalination process removes salts and other minerals from the water after which the chlorine is added to it, to match its taste with natural clean water. Today Desalination technology is used in 120 countries worldwide. But this technology has come under sharp criticism due to the high energy costs involved. Researchers have invented new systems that use the energy required for powering desalination plants from renewable resources. One such example is the solar powered desalination plant that harnesses sun's heat and converts it into energy, required to run the desalination plant [14]. Solar powered desalination plants are in operation in many countries and are proving very beneficial for the environment. Researchers in India have developed a water purifier that removes bacteria, viruses and even heavy metals from water using nanoparticles. Given the low income levels of most Indian families, the purifier will prove really beneficial as it will cost around Rs. 500 while the replacement cartridges will cost only Rs. 200 [15]. Researchers are also working on recycling waste water as it is estimated that $95 \%$ of the water that we use in our houses daily goes down the drain and ultimately ends up polluting oceans and estuaries and threatening our biodiversity and marine life. Thanks to technology, this problem has also been solved as researchers have invented a solar powered water recycling plant which uses waste water and filters it for reuse. While filtering the waste water, solid waste is sent for soil filling while the water is either reused for agricultural purposes or returned to the water cycle which has minimal environmental issues. It is estimated that globally $70 \%$ of fresh water use is for agriculture [16]. To reduce the wastage of water, researchers have designed an intelligent irrigation system which uses wireless sensor networks. These sensors are powered by solar energy and they transmit data wirelessly to a monitoring station. These sensors measure the soil moisture levels and accordingly provide water to the plants, thus proving very helpful in 
decreasing irrigation losses. Water consumption monitors are also now-a-days installed in homes to make people aware about their daily water consumption and it is proving beneficial in reducing the wastage of water.

\section{ROLE OF TECHNOLOGY IN CLEAN ENERGY DEVELOPMENT}

With the continuous depletion of energy resources, it is estimated that we will run out of fossil fuel reserves in a few decades. Providing energy for our future is becoming a major challenge and with each passing day a new technology is invented to generate energy from our renewable resources. Solar energy has been around for some time now but engineers have been able to scale up the technology and today massive solar power plants are in operation in many countries generating loads of energy. It is estimated that the amount of energy received by earth from sunlight in one hour can power up the world economy for a whole year [17]. With the advent of 3D printing technology, researchers in Finland have been able to print solar energy tree which generates and stores solar energy and can be used to power small appliances and mobile phones [18].In order to better utilise our land resources, researchers are putting solar panels on the surface of water which shades the water, reducing evaporation by up to $70 \%$ while slowing algae growth. The water also cools the solar panels naturally, resulting in higher power production [19]. Considering the benefits of this technique, the Government of India is also planning to setup a 50MW floating solar power plant in Kerala [20]. Another source of clean energy is wind. It is estimated that a $1 \mathrm{MW}$ turbine can generate electricity for 250 homes. The total installed capacity of wind power in the world in 2014 amounted to 369,553 MWs [21]. Wind turbines can be placed onshore as well as offshore. Geothermal energy is another efficient and eco-friendly way of generating energy from the earth's core. In this process water is turned into steam by the heat of the earth's core and this steam spins a turbine which drives an electrical generator. The steam once condensed is returned into the pipes to be turned into steam again and the process goes on. Tidal energy is another clean source of energy which converts energy obtained from sea waves into electricity. Tidal power plants are operational in many countries with South Korea having the world's biggest tidal power plant with a capacity of $254 \mathrm{MW}$. Russia is also planning to build two gigantic tidal power projects in Penzhina and Mezen Bay with a combined capacity of 102GW [22]. Researchers are working on harnessing tidal power in other regions as well and in the coming days more countries are planning to construct tidal power stations. While these sources are proving important in clean energy generation, Hydro power still remains the least costly option. The total installed capacity of hydro power in the world as of 2014 stood at $1036 \mathrm{GW}$ [23]. Hydro power accounts for $16 \%$ of the global electricity production and it is estimated to increase by $3.1 \%$ annually. It also accounts for $85 \%$ of the total global renewable energy production [24].

\section{ROLE OF TECHNOLOGY IN CREATING SUSTAINABLE CITIES}

Today more than half of the global population lives in urban areas and it is expected to touch $66 \%$ by the year 2050 [25]. More and more people are moving to urban areas due to the benefits that people enjoy in cities but overcrowding can disrupt the normal functioning of the city life, creating problems for both people and the government. To solve these problems advanced technological innovations need to be put in place. It is estimated that $40 \%$ of global energy and $25 \%$ of global water is consumed by buildings [26].To reduce energy consumption in buildings, new windows have been developed which are coated with metallic oxide to block sun's heat from coming in while retaining the heat inside, proving beneficial for both summer and winter season.Also solar energy and LED bulbs are being used extensively in buildings to further reduce energy costs and consumption. The other big problem that most of the cities face globally is that of rising waste levels. It is estimated that, every day, cities alone generate enough waste to fill a line of trash trucks almost 5000 kilometre long [27]. Municipalities have designed Energy-from-waste facilities where the waste is converted into energy. The waste is sent to a combustion chamber where it is burned and the heat generated in the process is used to boil water. The steam from the boiling water is used to rotate a turbine which generates power. The gases created in the combustion process are filtered and properly treated before being released into the environment. The ash that is left behind is also processed to extract metals for recycling before being sent for landfill [28]. Due to growing migration of people to cities, public transportation needs to be expanded as well. In cities across the globe new Metro lines are being constructed which while being convenient are low on carbon emissions. Globally there are an estimated one billion vehicles which consume half of the fuel that is produced [29]. Companies globally have also launched electric cars which are three times as efficient as cars with internal combustion engine. In Asia e-rickshaws are ferrying millions of people from one place to another. In many European cities e-Bicycle renting services are popular used.These days Google and other mappings apps are providing traffic details to the drivers and also providing them with alternate routes to avoid getting stuck on the way. 


\section{CONCLUSION}

While newer technological innovations hold the key for a sustainable world, often these innovations are patented making them almost inaccessible for the poorer countries. Due to rising public debt, higher inflation and weak exchange rates in countries like India, acquiring these technologies is very costly. Hospitals and other healthcare units are also one of the biggest polluters of the environment, generating millions of tonnes of waste each year. So there is a need to take advantage of the technology to make these units energy efficient while at the same time recycling the waste generated by these hospitals to the maximum possible limit. Many countries are still using coal fired power plants to generate energy as it is cheaper than other clean energy sources. The one billion plus vehicles on roads are still one of the worst emitters of greenhouse gases and with oil prices expected to further drop to $\$ 20$ per barrel, it is a challenge to replace them with green vehicles. Governments across the globe need to ensure that various technologies, necessary for sustainable development, are transferred to the developing countries at minimal cost. Likewise regulations should be put in place to limit the extraction of fossil fuels. Subsidies and tax rebated should be increased for green energy projects and a higher tax rate should be charged for non-renewable energy projects.

\section{REFERENCES}

[1] NOAA (National Ocean and Atmospheric Association), Where is all of the Earth's water?,http://oceanservice.noaa.gov/facts/wherewater/(Accessed December 2015)

[2] UN. (2013), World Population projected to reach 9.6 billion by 2015, https://www.un.org/development/desa/en/news/population/unreport-world-population-projected-to-reach-9-6-billion-by-2050/(Accessed December 2015)

[3] Mercy Corps. (2015), Quick facts: What you need to know about global hunger,https://www.mercycorps.org/articles/quick-facts-whatyou-need-know-about-global-hunger/(Accessed December 2015)

[4] World Watch Institute. (2011), Asia and Africa home to 95 percent of Global Agricultural Population, http://www.worldwatch.org/asia-and-africa-home-95-percent-global-agricultural-population/(Accessed December 2015)

$\begin{array}{llllll}\text { [5] ISAAA (2012), Global } & \text { Status } & \text { of } & \text { Commercialized } & \text { Biotech/GM } & \text { Crops: }\end{array}$ 2012,http://www.isaaa.org/resources/publications/briefs/44/executivesummary/

[6] CIPHET (2011): Central Institute of Post-Harvest Engineering and Technology Census, Primary Census Abstract Data, 2011, Government of India.

[7] IITKharagpur(2014),Solar power-driven portable cold storage to prevent food wastage, http://www.iitkgp.ac.in/shownews.php?Newsid=99/

[8] WHO (2015). Healthcare-Waste.http://www.who.int/mediacentre/factsheets/fs $253 / \mathrm{en} /$

[9] World Bank. (2012), Physicians (per 1000 people), http://data.worldbank.org/indicator/SH.MED.PHYS.ZS/countries/1WC8? display $=$ default

[10] Bolluyt J. (2014), 6 Healthcare Devices That Could Help Millions Of People, http://www.cheatsheet.com/technology/6-health-caredevices-that-could-help-millions-of-people.html/?a=viewall

[11] Jayalakshmi K. (2015),HIV and syphilis can be detected in minutes using cheap, lab-on-chip device,http://www.ibtimes.co.uk/hivsyphilis-can-be-detected-minutes-using-cheap-lab-chip-device-1486677/

[12] UN Water, An increasing demand, http://www.unwater.org/water-cooperation-2013/water-cooperation/facts-and-figures/en/(Accessed December 2015)

[13] Talbot D,The world's largest and cheapest reverse-osmosis desalination plant is up and running in Israel,http://www.technologyreview.com/featuredstory/ 534996/megascale-desalination/(Accessed December 2015)

[14] Hitachi, Solar-powered desalination Plants,http://www.hitachi.com/environment /showcase/solution/industrial/desalination plant (Accessed December 2015)

[15] Dinesh C. S. (2013),Bright lights of IIT Madras devise wonder water filter,http://indiatoday.intoday.in/story/iit-madras-studentsdevise-wonder-water-filter/1/269623/

[16] Seametrics. (2015), 10 Excellent Infographics about Water,http://www.seametrics.com/blog/water-infographics/(Accessed January 2016)

[17] Brown R.L. (2015),Sunlight Striking Earth's Surface in Just One Hour Delivers Enough Energy to Power the World Economy for an Entire Year, http://www.alternet.org/environment/sunlight-striking-earths-surface-just-one-hour-delivers-enough-energy-power-world/

[18] VTT. (2015), Solar power from energy-harvesting trees. http://www.vttresearch.com/media/news/solar-power-from-energyharvesting-trees- $\%$ e $2 \% 80 \% 93$-watch-the-video/(Accessed January 2016)

[19] Waterworld, Floating Solar Systems Provide Power, Environmental Benefits,www.waterworld.com/ articles/print/volume-27/issue9/editorial-features/floating-solar-systems-provide-power-environmental-benefits/(Accessed December 2015)

[20] Chadha M. (2014),India Plans World's Largest Floating Solar Power Project (50 MW), http://cleantechnica.com/2014/07/02/indiaplans-worlds-largest-floating-solar-power-project-50-mw/ (Accessed January 2016)

[21] GWEC. (2015), Global Wind Statistics,http://www.gwec.net/wp-content/uploads/2015/02 $\quad$ /GWEC globalwindstats2014 FINAL 10.2.2015/

[22] Shankleman J. (2014),The world's 10 biggest tidal power projects,http://www.businessgreen.com/bg/feature/2379437/the-worlds-10biggest-tidal-power-plants/

[23] IHA. (2014), World installed hydropower capacity, https://www.hydropower.org/ world-installed-hydropower-capacity-0/(Accessed January 2016)

[24] IEA (International Energy Agency). About hydropower. https://www.iea.org/topics /renewables/subtopics/hydropower/(Accessed January 2016) 
[25] UN. (2014),World's population increasingly urban with more than half living in urban areas, https://www.un.org/development/desa/en/news/population/world-urbanization-prospects/(Accessed January 2016)

[26] UNEP. (2012),Building Design and Construction: Forging Resource Efficiency and Sustainable Development, http://www.unep.org/sbci/pdfs/UNEP_SBCI_PositionPaperJune2012/

[27] World Bank. (2013), Global Waste on Pace to Triple by 2100,http://www.worldbank.org/en/news/feature/2013/10/30/global-waste-onpace-to-triple/(Accessed January 2016)

[28] Covanta,Understand How Energy-from-Waste Works,http://www.covanta.com/ sustainable-solutions/energy-from-waste/ (Accessed January 2016)

[29] UNIDO. (2013), Green Economy, https://www.youtube.com/watch?V=En1K6omlyMg (Accessed January 2016) 